DOI: $10.20472 / S S .2020 .9 .1 .003$

\title{
THE POWER AND THE FEMININE LEADERSHIP IN GENDER RELATIONS IN THE CASES OF NURSING
}

\section{DANELIA GÓMEZ-TORRES, KARLA SOFIA GÓMEZ-ALCÁNTARA}

\begin{abstract}
:
The article allowed to reflect the setting of the techno bureaucracy in representation of the head female nurse, their gender relations and, the confrontations for the changes of the "status quo", with purposes of discussing the positions of gender relations in the positions of management of nursing directors, methodology a qualitative study, directing through the study of case sustaining through the theory of strategic thought, the categories, the established paths in social aspects, gender power, institutional relations of nursing and leadership. The settings were health hospitals of the public sector of two countries. Social actors were four leading nurses, interviews with a semi structured guide, Concluding in order to efectualize the change of power one needs to adopt strategies of knowledge- power neutralizing negative power or threats, also in order to destruct leadership, ones needs to visualize successive interventions of the female, to generate

internal and external alliances as many feminine as masculine for the achievement of the objectives of the gender and to occupy sector spaces tied more to strategy.
\end{abstract}

\section{Keywords:}

Leadership, Nursing, Hospital administration, Gender Equity, Gender

JEL Classification: $\mathbf{J 7 9}$

\section{Authors:}

DANELIA GÓMEZ-TORRES, FACULTAD DE ENFERMERÍA Y OBSTETRICIA, UNIVERSIDAD AUTÓNOMA DEL ESTADO DE MÉXICO , Mexico, Email: gomezdanelia@usa.net KARLA SOFIA GÓMEZ-ALCÁNTARA, FACULTAD DE ENFERMERÍA Y OBSTETRICIA, UNIVERSIDAD AUTÓNOMA DEL ESTADO DE MÉXICO , Mexico, Email: sofia33gom@gmail.com

\section{Citation:}

DANELIA GÓMEZ-TORRES, KARLA SOFIA GÓMEZ-ALCÁNTARA (2020). THE POWER AND THE FEMININE LEADERSHIP IN GENDER RELATIONS IN THE CASES OF NURSING. International Journal of Social Sciences, Vol. IX(1), pp. 44-56., 10.20472/SS.2020.9.1.003 


\section{$1.1 \quad$ INTRODUCTION}

In this investigation we present a respective of the structures of power and leadership, that professionals practiced since the vision of gender relations, having the intention of analyzing the circumstances of the existence of power that nurses exercise during the management in public hospitals, as well as discussing the different positions in relation of gender in the process of management of the director nurses since the power structure in the health sector presents unique implications, represented by the central organizational structure, directed by the supposition that in the dialectic pole of that action indicates a weak visibility of the female nurse in charge of power (hegemonic ally carried out by male physicians). Making it possible to respond to; what is the power and leadership of the lead female nurse, in relation of gender inside the health institutions of the public sector? This way shows the necessity to make conscious the power that the nurse possesses in the techno-bureaucracy, or is it, the technical and administrative power whose professional maintains it by important manner, however in order that we recognize her use of this power; necessarily one should employ strategies, due to the confrontments for the change of status quo. Finally, we describe the principal aspects identified in the representation of power and leadership in the dynamics of female leading.

\subsection{METHODOLOGY}

It was about an investigation of qualitative nature, with a qualitative approach being able to be effective to clarify some aspects, or to give a more realistic idea about the information. The base theory was founded in the strategic thought theory, that which combines itself with the method of study of case. Most qualitative approaches involve theoretical ideas and concepts drawn from the review of the literature. These ideas and concepts may remain during the analyses and new ones may be incorporated as well (Padgett, 2015; s/p). 
This methodology presents a formulation of categories, permitting possible interpretations that correspond to the concrete aspects, and the practical consequences of discussion of the same. In its essence, this investigation studies power, in its category: categories, social aspects, genderpower, institutional relations of nursing and leadership, during the period in which the nurses were general directors of health institutions of the public sector of two countries. In the studied cases, the aspects of gender-power are dimensional zed, of four leading nurses which were the social actors of the investigation. They were interviewed, used as an instrument, a guide of semistructured type, containing ten open questions, facilitating the attraction of the nurses, the more relevant experiences of their level of power as a director. The ethical questions of the investigation were considered since the project was approved by an ethics committee and guarded the anonymity with the naming of cases giving them a number. For the organization of the data, processing of the attracted information with a matrix of categories was performed, having like evidences in that category. Finally obtaining information in series of the different studied cases, the strategy of simple and direct concurrent explanations were used, those which treat the true observed results and the consequences of other influences (Yin, 2014; 83). The proposed considerations were discussed through strategic thought that treats the matter as power permeating the feminine leadership in the hospital management. This theoretic construction makes possible the shaping of the results with the description of the characteristics of power in the field of the health sector to identify the said facts for the social actors to affix themselves in categories the joint aspects, social as much as the genders that emerge.

\subsection{RESULTS AND DISCUSSION}

A relation of gender is a means of referring to a social organization of the relations between the genders and a primary form of signifying the relations of power. However in the relation of power, differences are present that are translated in society in a given status, different and unequal to 
women and men being the first in many situations and inferior aspects and of subordination in relation to men, whose values always want to be dominant. Woman looks for independence in work, since the majority of the time her work is less prestigious, her less specialized work, are the men for the general rule, they possess the best positions in the organizational hierarchy. In many latin-american countries this inequality exists. This poses different challenges to women that include the impact of gendered understandings about their identities, lack of opportunities to develop networks, demands to balance work and life commitments, struggles with legitimacy at work, and limited opportunities for career progression (Rodriguez, 2019; 529), reflecting itself in the explanation in the following interview.

I believe that in this country, we are still lacking a little bit to accustom ourselves to the fact that we women are capable. But I think we have to see the factor of gender. I think also that this has to do with the fact that we are nurses, because since there are many nurses that they don't put themselves in their place, then the nurse... is seen just like other things (E-4).

Generally speaking, while management and administration are related to discipline, order and stability, leadership is associated with creative thought, tolerance of ambiguity and the impulse to generate constructive change. It is currently a fact that women are scarcely represented in senior management positions in private companies and public institutions in the Western world, although it can also be stated that in the intermediate levels of the job ladder and in positions with a medium level of responsibility, there is a greater balance between men and women (Rincon, $2017 ; 340)$.

I think so, I think because it was the truth, always recognized as less in Chile the more prepared professional in administration is the nurse, with relation to the rest of technicians, nutritionists, midwives, and all physicians, the nurses, at least in Chile, emerge with great force in the administrative part. Maybe because it will be perhaps for the classes, but we knew the feelings of the administration (E-3). 
It's mentioned that in the situation of competition for power, human manifestations of capital importance manifest themselves with reactions in sharing in that the professionals that maintain the leadership and will have to feel more their link, like the response of the doctors show before obtaining of power, upon assuming leadership of the hospital by a nurse considering it a confrontation for the medic. Attention toward assessing nurse leadership capacity should be a priority to meet workforce needs (Williams, 2019; 257).

When we saw the possibility of me, as a nurse, being a manager, the physicians reacted vehemently, strongly in the sense of impeding me from taking the position in my charge. They held various meetings with different representative entities and made an official signing (...) and then immediately I felt all the force of the medical corporation, against my assuming of the position (E-2).

In the context of the world of nursing work, it is relevant to understand issues involving power relations, class struggles and gender in order to subsidize critical positions and empower workers in the face of precarious working conditions and the weak social and professional recognition that permeate the profession (Dias, 2019; 2). In the fact of the inequality among men and women, in the strategy of ability to be able to understand the conceptions specifically with the relations of what is a man and what is a woman in respective political places, this was an addition to political places around this perception. That represents factually in the expression of the answers in the interview of the nurse who held the role of the general director in the hospital.

For me it was a tremendous impact, because I went to converse with the director of health services for another issue, and whatever thing I had imaged, but never that he would offer me the job of director of the hospital, for me, it was never within my expectations nor in my dreams, then it was a real thing, very new and very tremendous... I knew that besides this which was happening it was not me, the nurse, it was the nursing and then how tremendous to be at this juncture where I was (....), and I need to assume the challenges (E-3). 
In relation to power, there exists differences between sexes and the tendency has existed to socialize women in the familiar and social roles to facilitate the success of other people, historically, the woman was constituted to help or to complement the service of someone else, in that conception, of which she was lacking qualities to exercise the activities that denote power, still the fact is she has to go against the tide, since, historically, other categories exist, as in the case of the health field, that there are hegemonies in the world and these positions are assumed as we showed in a declaration made by a physician, and in the middle of communication, before the designation of a nurse to direct a hospital. This condition reinforces the challenge for nurses in management positions, as this strategic position presupposes the exercise of leadership, resolution of conflicts, assertive decision making, and achievement of outcomes: a situation that constantly analyzes their values, skills, personal and professional attitudes (Richter, 2019; 48).

In the past 50 years, the physicians direct that type of hospitals with the best international results demonstrated in all fields. How is it possible that 'doctors' with the highest standards, qualifications and tremendous vocation of service and dedication, that they are put into that form? (La Cuarta: 2004).

An analysis covering the leadership of nurses in two cases was sizing by the mass media who gave a more faithful account of the development of an administrative-legal determination, social and political before the population. That impact was generated due to the legal change with national character, of the profile of the candidates to directors of hospitals, due to the medical union putting ardent pressure on a local, regional, and national lever to examine the law and avoid nurses exercising the function of director of a hospital.

A very uncomfortable situation was created for all the professions, especially for the medical area, since they saw their power limited (...) The great difficulty was principally among the physicians, because they did not accept us, they boycotted us by every form possible, it was a boycott openly and continually (E-1). 
To achieve that was to reaffirm that they alone were able to exercise the work of direction, only five professionals. (Civil and commercial engineers, accountants, orthodontists, and, of course, physicians) excluding among them the nurses. This was because of the strong pressure from the physician's union with the Governmental institutions and national bureau.

Family doctors of the area: the professionals reject that the faculty has been marginalized by the direction of the hospitals, and that in their places nursed were assigned (La Tercera: 2004).

In fact as components that include important aspects, such as change of attitude, that happen as an action made by means of corresponding power and the legal and administrative branches, whose fields of competence and actions are ruled by men. Therefore, both females and males are equally responsible for gender-related discrimination found in the workplace (Wu, 2019; 123). Female leadership: Each organization needs a leader, the leadership is necessary because of the imperfect organizational design, traditionally governmental and health organizations are being administrated through a hierarchy distribution of power, usually as a process of control that goes from top to bottom.

Leadership in the organization has acceptance because the organization is an open system affected by the environment where he is at and it has an interchange of energy that modifies continually in the search for balance with the environment, another reason is because of the human nature affiliation in the organizations, this affiliation is segmentary nature that means it takes just one part of the whole being that develops another activity and has affiliation with other groups to satisfy their needs, this aspect of extra-organizational affects the life and behavior of the person in the organization. It is important to mention that women as administrators use a style of leadership more than men. It has been proved that women conceives leadership as a way to transform, change and redimentionalize their personal interests and of their followers and the whole company. Female nursing managers should apply a significant leadership style, to improve the outcomes in other groups of health-care management (Shirazi, 2016; 326). 
I think there are differences in reality, the physician still has an absolute biomedical vision, in the same case because of the nurse's formation of the work that she does, I can say for her different experiences (...) we have a more holistic vision, much more dissected for health, as a whole being from the emotional point of view, it is for this that I think our formation is different, according to the technical experiences, in the sense of administration that is one of our strengths $(. . .$.$) Also in interpersonal relations we are not self-centered, but instead, we have a$ closer relationship with people, a closer language, a better understanding of the human process in which people are going through, we can see all that in the context of a family, we, as a definition, are professionals of help, a profession of interaction, for this reason it is not the same and I think that a hospital, even in the biomedical area, can be perfectly directed by a nurse (E-4). The presence of women, in both the field of education and in the world of work, has undergone substantial changes in recent decades. Currently, most women encounter no obstacles to accessing higher education, and the increase in their level of education has been noticeable in recent years. However, it must be mentioned that the preferences of men and women are still different when deciding upon higher education (Rincon, 2017; 332). Feminine values stimulate the work team, the collaboration and interdependency, it adapts better to human resources and to the strategic organization. Per say, in fact as a result some women adapt a traditional structure of power to direct their followers. Because institutions traditionally are controlled by a masculine hierarchy, in that the leader has been a man. According Arenas-Molina $(2017 ; 123)$ whichever woman that wants to reach the highest point has to know the masculine properties; moreover the feminine strength system functions in the strategy of the organization. It is said that traditionally, women demonstrate, at maximum, a social politic and resources in which she finds ambivalence, in relation to the concept of power, until very recently, in an open form, the search of power was avoided, this happened from the fact that women had been socialized in a different way in facing the power of men because for them power is seen as a domination and for them is a submission. 
The leadership in a group that is not even, the same as in a health institution with people of different backgrounds and formation, only would be able to function in the scheme of liberal active and democratic participation, where every intermediate boss and superior leader, because of their formation and temperament, are located in the position to guide the group with less preparation. Much of what happened with power had depended on the authenticity and desire of the highest direction to create opportunities in which individuals that work in the organization maximize their personal development, this happened through the recognition of the profile of each one of the individuals, being able to conduct a motivation to all the members of the social organism through the objectives of the institution as we show in the next answer of the interview It was there that I implanted a strategic plan of work that is the knowledge of administration that we nurses possess. I say this because we are the ones who dedicate the most to administration. These are the things that physicians will never do, because they are not in the same level of the organization nor the process. We work with a process. This is our day to day work, for us it is not strange that we have described procedures nor that we have a plan of work, we have everything described as a chain of factors that ended to cover the final objective (E-3).

In their characteristics as leaders, the nurses are figures of projection and collaboration in the social community, from these figures selected for leadership there are people that typically are charismatic leaders, from their own being emanate power and personal sympathy, endowed with strange ability to conduct, they have a capacity to challenge the current gender status quo in management and leadership (Adamson, 2019; 986). .People that they have behind themselves a huge amount of experience accumulated in organizations, which gives power, understanding the term power in the organizational environment it is defined basically as the power of production and to mobilize people and resources to achieve the goal. 
Now being a woman, a nurse, are deeper characteristics associated with the lack and absence of power, quite often the nurse is seen with an excess of work, a perfectionist, and refuses to delegate tasks, this remains patented in the expression we will be showing next.

"So I have to correspond to the expectations and I did my best for that and for nursing, for the institution I had my responsibility as a professional, so, many times I knew that the personnel would say, "... Oh, how good...it is what you are doing now." Why? Because I socialized, when I went through my presence was not without form, without flavor, without smell or invisible. (E-2) Their ability to work in front of the institution is admired and respected for their highest intellectual and moral standards that lead to leadership, historically, nursing professionals have emerged as leaders of the health team, due to their training and professional development, with a broad vision of the human being, of care and health (Carcamo-Fuentes, 2019; 73), leadership guarantees efficiency in the fulfillment of tasks to maintain the work of supervisors in management through the administration of nursing care. From this statement it is important to say that: Authority and leadership are concepts correlated with power and also influence, it is said that women in positions of power, in health institutions in our times are more likely to recognize their internal capacities that support to use power efficiently.

How to explain what has occurred until now, with professional women, the ones who possess the technical and professional attributes, and never incur in high director positions in health service. Considering that the political ability for the creation of consensus, inclusion and involvement, are also necessary, and these abilities usually are associated with the feminine characteristics. According to Muniz (2018; 365), we are clearly amidst a period of change brought on by globalization and technological development that has transformed the dynamics and structures of different social spheres, including family and the world of work. As such, psychological science plays a fundamental role in identifying and understanding gender in its new context, but also in designing strategies to ensure that the challenges of this transition do not prevent women from achieving their full potential 


\subsection{CONCLUSION}

This study allowed the application of strategically thought as to comprehend that in order to effect a change of power, itself it is important to adapt a strategy of knowledge-power. The challenge requires some strategies, which implicate the neutralization of negative powers or threats to assume the power, with substantial changes in the positionment of women, also demonstrated that to eliminate opposing powers to the positionment of power in positive space it is necessary to destruct hegemony, through professional values, through the manifestations and visibility in the intervention of the successful woman, generating an ideological and cultural development in a social process, this position implies the termination of the new role of women, promoting internal and external alliances, as many feminine as masculine to achieve the objectives of gender, which allows the diminishment of the hegemonic power of men. This means to validate the knowledge and interests, determining objectives and looking to make the strategies adequate, in this way, if we verify that our strong are few, so the tendencies need to be to occupy sartorial spaces more linked to our strategy, with the implementation and ideological diffusion among social groups, potentially the same.

Women require interactional and transformational leadership, this interactive leadership implies to share power, information, induction to participation, with the importance of knowledge which each person has. High determination is required to demonstrate high compromise with the profession and the organization and to be able to overcome obstacles, this transformational leadership is able to create synergetic environments which favor the changes. Because of the characteristics of this leadership, it is appropriate that a woman exercise it, because she has the capacity, to perceive what is hidden behind attitudes and words, to predict what is coming and react before the problem worsens. Because of the intransitive of women, they need to look in the social human ability, the psycho-physic social capacity, of the woman in collective work, in the circumstances of services and this construction focalizes the structure, for the development and the continued support of the relations between professionals to work together. In the 
transformational leadership, it has high standards, high compromises with the profession, which is centered in the person, it takes into consideration the influence exercised through her actions as a leader, under subordinates and leadership toward that construction of the different man society project; the change occurs because of the futuristic focus of the transformational leader.

\section{References}

ADAMSON, M. and KELAN, E. K. (2019) Female heroes': Celebrity executives as postfeminist role models. British journal of management. 2019. Vol. 30, No. 4, s. 981-996. https://doi.org/10.1111/14678551.12320

ARENAS-MOLINA, M. T; CALAMA, R. J. and NUÑEZ, D. T. (2017) Leadership in construction. A case study with a gender perspective. Journal of the construction. 2017, Vol. 16, No. 1, s. 115-125. https://doi.org/10.7764/RDLC.16.1.115

CARCAMO-FUENTES, C. and RIVAS-RIVEROS, E. (2017) Leadership Style among Nursing Professionalsn Acording to their Role in the Public or Private Sectors in Tecomuco, Chile. Aquichan. 2017, Vol. 17, No. 1, s. 73-80. https://doi.org/10.5294/aqui.2017.17.1.7

DIAS, M. O; SOUZA, N. V; PENNA H.G. and GALLASCH C. H. (2019) Perception of nursing leadership on the fight againist the precariousness of working conditions. Revista da escola de enfermagem da USP. 2019, Vol. 53, No. 3, s. 1-7. Aviable at http://www.scielo.br/pdf/reeusp/v53/en_1980-220X-reeusp-53e03492.pdf

LA TERCERA, Mèdicos generales de zona anuncian movilizaciones. Aviable at http://www.tercera.clitarticulo0.5819,3255_5690_00.html

LA CUARTA. Matasanos denuncian vedette de Ministerio. Aviable at http://www.lacuarta.cldiario/2003/06/27/27.07.CRO.MEDICOS.html

MUNIZ, P. R. and DE SOUZA, F. D. (2018) Female Leadership Talent Development: The Brazilian Context. Advances in Latin American Psychology. 2018, Vol. 36, No. 2, s. 363-372. https://doi.org/10.12804/revistas.urosario.edu.co/apl/a.4619

PADGETT, D. (2016) Qualitative Methods in Social Work Research. 3a ed. New York: SAGE publications

RICHTER, S. A; DOS SANTOS E. P; KAISER. D. E. (2019) Being an entrepreneur in nursing: callenges to nurses in a strategic leadership position. Acta paulista de enfermagem. 2019, Vol. 32, No. 1, s. 46-52. https://doi.org/10.1590/1982-0194201900007

RINCON, V; GONZALEZ, M. and BARRERO, K. (2017) Women and leadership: Gender barriers to senior management positions. Intangible Capital. 2017, Vol. 13, No. 2, s. 319-352. https://doi.org/10.3926/ic.889

RODRIGUEZ,J. K; RIDWAY, M. and KEMP L.J. (2019) Women, work and management in the Middle East. Guest editorial. 2019, Vol. 34, No. 7, s. 529-540. Aviable at https://www.emerald.com/insight/content/doi/10.1108/GM-10-2019-186/full/pdf?title=guest-editorial

SHIZARI, M; EMAMI, A. H; MIRMOOSAVI, S.J. (2016) The effects os intervention based on supportive leadership behavior on Iranian nuersing leadership performance: a randomized controlled trial. Journal of nursong management. 2016, Vol. 24, No. 3, S. 323-327. https://doi.org/10.1111/jonm.12335 
WILLIAMS, M. P. And LI, Y. (2019) North Carolina Nurse Laeader Project a replication study to assess nurse leadership capacity. Journal of nursing administration. 2019, Vol. 49, No. 5, s. 256-259. https://doi.org/10.1097/NNA.0000000000000747

WU, B; BHULANI, N; JALAL, S; DINJ, J. (2019) Gender disparity in leadership positions of general surgical societies in North Amercia, Europe and Oceania. Cureus. 2019, Vol. 11, No. 12, S. 120-126. https://doi.org/10.7759/cureus.6285

YIN, R. (2014) Estudo de caso: planejamento e métodos. 5ªed. São Paulo: Bookman. 